\title{
Effect of some Bacterial Bioagents against Root- Knot Nematode (Meloidogyne incognita race2)
}

\author{
Gitanjali Devi*, L.C. Bora
}

\author{
*Department of Nematology, ${ }^{2}$ Department of Plant-Pathology, Assam Agricultural University, Jorhat, Assam, India \\ Email: gitanjali_devi@yahoo.in
}

\begin{abstract}
The effect of culture filtrate of different bacterial isolates on egg hatching and juvenile mortality of root-knot nematodes (Meloidogyne incognita race 2) was studied in vitro and the effective strains were selected. The per cent mortality and hatching inhibition was proportional to the concentration of culture filtrate and the duration of exposure period. Culture filtrate of all the isolates of bacteria significantly induced mortality and inhibition of egg hatching of $M$. incognita juveniles. The highest percentage of inhibition of egg hatching was recorded for Bacillus thuringiensis followed by Bacillus sp. and Pseudomonas fluorescens whereas the highest percentage of mortality of juvenile was recorded for Bacillus thuringiensis followed by Pseudomonas fluorescens and Pseudomonas sp.
\end{abstract}

Keywords: Rhizospheric bacteria, egg hatching, juvenile mortality, culture filtrate, duration of exposure period, root-knot nematode.

\section{INTRODUCTION}

Root-knot ne matode Meloidogyne incognita race 2 is one of the major constraints in crop production in Assam. Present strategies for nematode management largely depend on cultural practices such as crop rotations, use of resistant varieties and use of nematicides which has several disadvantages. Utilization of biocontrol agent is of advantage over the above mentioned nematode management strategies. Many species of Pseudomonas and Bacillus have been reported as plant growth promoting rhizobacteria (PGPR) which produces iron-chelating siderophores, antibiotics or hydrogen cyanide, and these compounds have been implicated in the reduction of deleterious and pathogenic rhizosphere microorganisms, creating an environment more favourable for root growth[1]. It has been demonstrated that bio-agents produce different metabolites and antibiotics which directly or indirectly stimulate plant growth [2] . A number of bacterial species has been used as biocontrol agents against Meloidogyne spp. [3-12]. However, few biocontrol products are currently commercially available and it is necessary to find different strains of antagonistic bacteria for controlling plantparasitic nematodes more efficiently. Therefore, a laboratory bioassay was carried out to test some of the isolated strains of Bacillus and Pseudomonas for their nematicidal activity.

\section{MATERIAL AND METHODS}

\section{Isolation of bacteria}

A survey was conducted during Feb 2018 to May 2018 in different localities of the district Jorhat, Assam comprising an area approximately 500 ha, in order to identify the nematodes infection and to isolate the bacterial antagonists fro $\mathrm{m}$ crops rhizosphere viz. cucurbits, tomato, brin jal, okra, cabbage, banana, citrus, and tea. A total of 50 soil (500 g) sample were collected from the rhizosphere of each crop. Serial dilution technique was used for the isolation of bacterial strain. One $\mathrm{g}$ of rhizosphere soil was dispensed in $9 \mathrm{ml}$ sterile water, from the $10^{-6}$ dilution, $50 \mu \mathrm{l}$ were inoculated over Petri plates containing Nutrient Agar and King's B agar media (autoclaved at $121^{\circ} \mathrm{C}$ for $15 \mathrm{~min}$ ) separately. The plates were incubated at room temperature $28 \pm 2{ }^{\circ} \mathrm{C}$ for $48-72 \mathrm{~h}$. The colonies obtained on plates were picked and streaked on more plates and purified by restreaking. The isolates were initially categorized into two broad groups based on Gram staining by Hucker's modified method [13]. The isolated strains were identified by up to generic level by Bergey's manual and using standard protocol $[14,15]$. Two is olates namely Pseudomonas sp. and Bacillus sp. were collected from soil rhizosphere of cowpea and banana respectively. Pseudomonas fluorescens, Bacillus thuringiensis, B.brevis were procured from the Department of Plant Pathology, AAU, Jorhat, Assam. All the strains were evaluated for ne maticidal properties against nematodes.

Nematode inoculum and mass culturing

The inoculum of root-knot nematode $M$. incognita race 2 was collected from naturally infested tomato crop in field and single egg mass was used to raise pure culture. Mass culturing of nematodes was done on tomato variety Sel 7, in 
order to get regular supply of the inoculums for the experiments. One month old tomato seedlings were inoculated with small volume of egg suspension approximately consisting of 2000 eggs of M.incognita race 2. These pots were watered and kept in glasshouse at temperature $28-35^{\circ} \mathrm{C}$.

Preparation of culture filtrate and test for nematoxicity of bacterial culture filtrate

The bacterial isolates were inoculated in the respective medium $(40 \mathrm{ml})$. Pseudomonas on King's B broth and Bacillus on Nutrient broth were separately incubated at $30^{\circ} \mathrm{C}$ on a shaker for $48 \mathrm{hrs}$. The liquid culture was filtered through Whatman No.1 filter paper and passed through bacterial filter[16] .Filtrates were centrifuged at $6000 \mathrm{rpm}$ for $15 \mathrm{~min}$. The supernatant was taken and the suspended residue was discarded.

\section{Juvenile mortality test}

One $\mathrm{ml}$ of $\mathrm{S} / 2, \mathrm{~S} / 8, \mathrm{~S} / 32$ dilutions of each cell-free culture filtrates was mixed with $1 \mathrm{ml}$ nematode suspension (containing ca. 100 M.incognita J2) in cavity block to obtain S/4, S/16 and S/64 dilutions and tested for per cent mortality of nematodes. There were 3 replications for each treatment. Observations were taken after $24 \mathrm{~h}, 48 \mathrm{~h}$ and 72 h. The immobile J2 were confirmed for mortality by randomly disturbing with a needle. Sterile water and medium alone served as control. The per cent juvenile mortality was calculated by the following formula.

$$
\text { Percent mortality }=\frac{\text { Total number of dead juveniles }}{\text { Total number of juveniles }} X 100
$$

\section{Fgg hatching test}

To determine the effect of culture filtrate on the hatching of eggs of $\mathrm{J}_{2}$ of $M$. incognita eggmasses of M.incognita were dissolved in $\mathrm{NaOCl}$ to release individual eggs [17]. Sterilized Petri dishes of $5 \mathrm{~cm}$ dia were separately pipette 1 $\mathrm{ml}$ of culture filtrate with dilution $\mathrm{S} / 2, \mathrm{~S} / 8$ and $\mathrm{S} / 32$. Hundred eggs of M.incognita in $1 \mathrm{ml}$ water suspension were transferred to each dish. Medium alone and water alone served as control. All Petri dishes were kept at $28 \pm 2^{\circ} \mathrm{C}$, replicated thrice. Observations were recorded on after 5, 10 and 15 days. The per cent egg hatch was calculated by the following formula.

$$
\text { Hatching } \%=\frac{\text { No. of hatched juveniles }}{\text { No. of hatched }+ \text { unhatched eggs }} X 100
$$

\section{Statistical analysis}

Per cent egg hatch and per cent mortality data was subjected to statistical analysis using the three factorial completely randomized design statistical package. The critical differences in main effects i.e. isolates, concentration, and time of exposure as well as in their interactions were tested at $\mathrm{P}=0.05$.

\section{RESULTS}

Two numbers of isolate of bacteria were isolated from the root rhizosphere of M.incognita race 2 infected plants. Bacillus sp. and Pseudomonas sp. were isolated from rhizospheric soil of banana and brinjal, respectively. The results presented revealed significant differences in juvenile mortality of M.incognita among isolates (biocontrol agent) $(\mathrm{T})$, concentration of culture filtrate $(\mathrm{C})$ and exposure period (t).

The data showed in the Table 1 revealed that all the culture filtrates of bacterial is olates were having nematicidal effect of varying degree on M.incognita race 2. Per cent mortality of nematodes was directly proportional to the concentration of culture filtrate and the period of exposure. Irrespective of concentration of culture filtrate $(\mathrm{C})$ and duration of exposure (t), six isolates namely Bacillus sp., B.brevis B.thuringiensis, Pseudomonas sp., P.florescence and P.aeruginosa were exhibited nematicidal effects on $M$. incognita $\mathrm{J}_{2}$. Irrespective of concentration of culture filtrate and exposure period the mortality rates of $M$. incognita $\mathrm{J}_{2}$ caused by B.thuringiensis reached $75.77 \%$ at which is at par with P.florescence (75.44\%).All the new isolate namely Bacillus sp, and Pseudomonas sp displayed more than $40 \%$ juvenile mortality during $24 \mathrm{~h}$ exposure time at S/16 concentration of culture filtrate. On the other hand, P.aeruginosa showed the lowest toxicity, caused only $48 \%$ juvenile mortality $\mathrm{S} / 64$ at concentration of culture filtrate during $48 \mathrm{~h}$ exposure time. Irrespective of isolate and period of exposure the mortality rate of $M$. incognita $\mathrm{J}_{2}$, at lowest concentration $(\mathrm{S} / 64)$ is $43.62 \%$ whereas at highest concentration $(\mathrm{S} / 4)$ mortality rate is $51.66 \%$.Similarly irrespective of isolate and culture filtrate concentration the mortality rate of $M$. incognita $\mathrm{J}_{2}$ is highest $(63.07 \%)$ at $72 \mathrm{~h}$ exposure period and lowest $(34.85 \%)$ at $24 \mathrm{~h}$ exposure period. B.thuringiensis and P.florescence showed highest toxicity (100\% J2 mortality) at S/16 concentration of culture filtrate during $72 \mathrm{~h}$ exposure period. There was least effect of media on juvenile mortality of $M$. incognita.

The results presented in Table 2, revealed significant differences among isolates ( $\mathrm{T})$, concentration of culture filtrate $(\mathrm{C})$ and exposure period (t) in egg hatching of $M$. incognita. Irrespective of concentration of culture filtrate (C) and time of exposure period (t), the culture filtrate of B.thuringiensis followed by, Bacillus sp., P. fluorescens and Pseudomonas sp. adversely affected the larval hatching of 
M.incognita race 2. Similarly, irrespective of isolate (T) and concentration of culture filtrate $(\mathrm{C})$, time of exposure $(\mathrm{t})$ also affected the larval hatching. With increase in exposure period up to 15 days there was a correspondingly increased in egg hatching. Hatching of $M$. incognita $\mathrm{J}_{2}$ is highest $(57.03 \%)$ at 15 day exposure period and lowest $(40.00 \%)$ at 5 day exposure period. With increase in the dilution of culture filtrate, the cumulative hatching was increased irrespective of isolate (T) and time of exposure period (t). Highest inhibition in hatching was obtained in $\mathrm{S} / 4$ concentration of each bacterial culture filtrates. The percentage hatching of M.incognita was 38\% for 15 day of exposure period in the $\mathrm{S} / 64$ concentrations of culture filtrates of B.thuringiensis followed by Pseudomonas sp. with percentage hatching of 48. B.brevis and P.aeruginosa showed negligible effect on inhibition of egg hatching of M.incognita. There was negligible effect of culture media on hatching of M.incognita.

\section{DISCUSSION}

Culture filtrates of several soil borne microbes are known to exhibit nematicidal action besides inhibiting larval emergence of plant parasitic nematodes. Antibiotics, extracellular en zy mes and other toxic compounds present in metabolites of rhizobateria are probably involved in the increase of $J_{2}$ mortality and the inhibition of egg hatching[18]. The lethal effect of the cultural filtrates of these bacteria may be attributed to the production of nematicidal metabolites i.e. lytic enzymes (gelatinase, protease and chitinase) and volatile compounds in the cultural media. Similar results were reported by Ali et al. [19] who found that cultural filtrates of Pseudomonas sp. caused juvenile mortality of $M$. javanica. The nematicidal volatile products that were produced by Bacillus and were characterized to include mainly the benzene acetaldehyde, 2-nonanone, decanal, 2-undecanone and dimethyl disulphide, which were active against $M$. incognita juveniles and eggs at the concentration of $0.5 \mathrm{mmol}$ [20]. Ahl et al., [21] proposed the mechanis m of reduction of nematode population which was due to premature egg hatching and reduction in viability and mortality of juveniles induced by secondary metabolites such as 2,4 Diacetylphloroglucinol and lytic enzy mes [22], antibiotics and hydrogen cyanide produced by Pseudomonas spp. and non cellular extract and toxic metabolites like bacillopeptidase, subtillin E and a lactamase from Bacillus spp. Regina et al. [23] and Hanna et al. [24] have reported that mortality of $M$. incognita increased with increase in exposure time as well as the concentration. The effects of rhizobacterial toxins include the suppression of nematode reproduction, egg hatching and juvenile survival, as well as direct killing of nematodes by causing paralysis and convulsive movements [4]. Dhawan et al. [25] evaluated four strains of Bacillus thuringiensis, and found that the mobility of M.incognita juveniles completely ceased after $24 \mathrm{~h}$ exposure in $\mathrm{S}$ and $\mathrm{S} / 10$ dilutions. However, all dilutions above S/25 were ineffective. Production of surfactin by Bacillus is a characteristic that supports their persistence under extreme conditions [26, 27]. El-Hamshary et al. [28] found that Pseudomonas fluorescens and Pseudomonas aeruginosa affected $M$. incognita juvenile survival in vitro study, and the mortality percentages of the nematode were dependent on the bacterial concentration and exposure time. Terefe et al. [29] found that an aqueous suspension of Bacillus firmus at 2.5 and 3\% concentration caused $100 \%$ inhibition of mobility $M$. incognita, 24 hrs after treatment. The mortality percentage of Bacillus circulans (KSB2) at dilutions of $1 / 100$ and $1 / 1000$ were the highest inhibitors comparing with the other tested bacteria being 97.8 and 40.3\%, respectively [30]. Xia et al. [31] reported that the culture supernatant of $B$. subtilis strains caused a higher mortality of $M$. incognita $\mathrm{J}_{2}$. Nagesh et al. [32] observed that, cell-free culture filtrates of $B$. cereus reduced egg hatching (90\%) and caused $100 \%$ mortality of juveniles. Bin et al. [33] mentioned that culture filtrates of rhizobacterium are heat stable and resistant to extreme $\mathrm{pH}$ values, which suggested that the antibiotic action might be responsible for the nematicidal activity. The exposure of $M$. incognita to various concentrations $(5-100 \%)$ of cultural filtrate of Paenibacillus polymyxa in vitro conditions significantly reduced egg hatching and caused substantial mortality of its juveniles [34]. These results are similar with the findings of Ying et al. [35] who reported Bacillus spp. culture could significantly inhibiting the hatching of eggs and increases the mortality of second stage juveniles and reduce infection of the nematode through production of nematicidal volatiles. Antibiotic production viz., 2, 4 DAPG, phenazine and pyocyanine were also well pronounced in the Pseudomonas strain, Pf 128 through thin layer chromatography [36] .The failure to regain its activity of $M$. incognita after separating from culture filtrate of Pseudomonas spp. placed over sterile water demonstrates the numbers of metabolites that had longer systemic activity $[37,38]$.

\section{CONCLUSION}

It is clear from this work that, there are many bacteria which have potentialities for controlling root-knot ne matode in plant rhizosphere region. A mong six bacterial isolates Bacillus thuringiensis and Pseudomonas fluorescens were 
exhibited the highest production of nematicidal activities against root-knot nematode $M$. incognita race 2 .

\section{ACKNOWLEDGEMENT}

The authors are thankful to the Head of the Department, Department of Nematology for providing necessary facilities for conducting the experiment.

\section{REFERENCES}

[1] Siddiqui, Z. A. and Mahmood, I. 2006. Role of bacteria in the management of plant parasitic nematodes, a review. Bioresource Technology 69: 167-179

[2] Kloepper. J. W., Zablotowiz, R. M., Tippimg, E. M. and Lifshitz, R. 1991. Plant growth promotion mediated by bacterial rhizosphere colonizers. In: The rhizosphereand plant growth. D.L. Ke ister and P.B. Cregan. (eds.).Kluwer Academic Publisher s, Dordr echt, the Netherlands. 315-326 pp.

[3] Gokte N and Swarup G. 1988. On the potential of some bacterial biocides against root-knot and cyst nematodes. Indin Journal of Nematology 18: 152-153.

[4] Siddiqui, Z.A. and Mahmood, I. 1999. Role of bacteria in the management of plant parasitic nematodes: A review. Bioresource Technology 69: 167-179.

[5] Neipp, P.W. and Becker, J.O. (1999) Evaluation of biocontrol activity of rhizobacteria from Beta vulgaris against Heterodera schachtii. Journal of Nematology 31: 54-61.

[6] Tian, H., Riggs, R.D. and Crippen, D.L. 2000. Control of soybean cyst nematode by chitinolytic bacteria with chitin substrate. Journal of Nematology 32: 370-376.

[7] Siddiqui, I.A. and Shahid, S.S. 2003. Suppression of root-knot disease by Pseudomonas fluorescens CHA0 in tomato: importance of bacterial secondary metabolite, 2,4-diacetylpholoroglucinol. Soil Biology and Biochemistry 35: 1615-1623.

[8] El-Nagdi, W.M.A. and Youssef, M.M.A. 2004.Soaking faba bean seed in some bio-agents as prophylactic treatment for controlling Meloidogyne incognita root-knot nematode infection. Journal of Pest Science 77: 75-78.

[9] Huang, X.W., Tian, B.Y., Niu, Q.H., Yang, J.K., Zhang, L.M. 2005. An extracellular protease from Brevibacillus laterosporus G4 without parasporal crystals can serve as a pathogenic factor in infection of nematodes. Research in Microbiology 156: 719-727.

[10] Mendoza, A.R., Kiewnick, S.,and Sikora, R.A. 2008. In vitro activity of Bacillus firmus against the burrowing ne matode Radopholus similis, the root-knot nematode Meloidogyne incognita and the stem nematode Ditylenchus dipsaci. Biocontrol Science and Technology 18: 377-389.

[11] Ashraf, S.M. and Khan, T.A. 2010. Integrated approach for the management of Meloidogyne javanica on eggplant using oil cakes and biocontrol agents. Archives of Phytopathology and Plant Protection 43(6): 609-614.

[12] Wei, L.H., Xu, Q.Y., Wei, B.Q., Wang, Y.M.and Li, S.M. 2010. Screening of antagonistic bacterial strains against Meloidogyne incognita using protease activity. Biocontrol Science and Technology 20: 739-750.

[13] Rangaswami, G. and Bagayaraj, D. J. 1993. Microbial Biotechnology. In: Agricultural Microbiology. Prentice Hall of India Pvt. Ltd., New Delhi. 389-405 pp.

[14] King EO, Ward MK. and Raney DE. 1954. Two simple med ia for the demonstration of pyocyanin and fluorescin. Journal of Laboratory and Clinical Medicine 11: 441-449.

[15] Buchanan, R.E. and Gibbons, N.E. 1974. Bergey's Manual of Determinative Bacteriology. Baltimore, Williams \& Wilkins, 8th edition, pp. 13-45.

[16] Aalten, P. M. and Gowen, S. R. 1998. Entomopathogenic nematodes and fluorescent Pseudomonas rhizosphere bacteria inhibiting Radopholus similis invasion in banana roots. Brighton Crop Prot Conference of Pests Disease 2: 675-680

[17] Hussy, R. S. and Barker, K. R. 1973. A comparsion of method of collecting inocula of Meloidogyne spp. including a new technique. Plant Disease Reporter 57 (12): 1025-1028

[18] Khan, T. A. and Hussain, S. I., 1984, Effect of culture filtrate of eight Aspergillus spp. on the hatching and mortality of Meloidogyne incognita. Indian Journal of Nematology 14: 51-54.

[19] Ali, N.I., Siddiqui, I.A., Shahid Shaukat, S.and Zaki, M.J. 2002. Nematicidal activity of some strains of Pseudomonas spp. Soil Biology and Biochemistry 34: 1051-1058.

[20] Lindberg ,GS.1981. An antibiotic lethal to fungi. Plant Disease 65:680-683

[21] Ahl, P., Voisarad, C. and Defago, G. 1986. Iron siderophores, cyanic acid and antibiotics involved in suppression of Thielaviopsis basicola by Pseudomonas fluorescens strain. Journal of Phytopathology 116: 121-134

[22] Dunne, C., Moenne-Loccoz, Y., McCarthy, J., Higgins, P.,Powell, J., Dowing, D. N. and Gara, F. O. 1998. Combining proteolytic and phloroglucinol- 
producing bacteria for improved biocontrol of Pythium-mediated damping off of sugarbeet. Plant Pathology 47: 299-307.

[23] Regina, M.D.G.C., DeSouza, I.S., Belarmino, L.C. 1998. Nematicidal activity of Bacillus spp. strains onjuveniles of Meloidogyne javanica. Nematologia Brasileira 22: 12-21.

[24] Hanna, A. I., Riad, F. W. and Tawfik, A. E., 1999. Efficacy of antagonistic rhizobacteria on the control of root-knot nematode, Meloidogyne incognita intomato plants. Egyptian Journal of Agricultural Research 77(4): 1467-1476.

[25] Dhawan, S.C., Narayanan, R. and Babu, N.P. 2004. Biomanagement of root-knot nematode, Meloidogyne incognita on okra by Paecilomyces lilacinus. Annals of Plant Protection of Sciences 12: 356-358

[26] Kloepper, J. W., Ryu, C. M. and Zhang S. A. 2004 Induced systemic resistance and promotion of plant growth by Bacillus spp. Phytopathology 94: 12591266.

[27] Joshi, R. and Gardener, M. B., 2006. Identification of genes associated with pathogen inhibition in different strains of B. subtilis. Phytopathology 96: 145-154.

[28] El-Hamshary, O.I.M., El-Nagdi, W.M.A. and Youssef, M.M.A. 2004. Geneticalstudies and antagonistic effects of a newly bacterial fusant againstMeloidogyne incognita root-knot nematode, infecting sunflower and plantpathogen, Fusarium oxysporum. Journal of Genetic Engineering and Biotechnology 2(2):233-246

[29] Terefe, M., Tefera, T. and Sakhuja, P.K. 2009. Effect of a formulation of Bacillus firmus on root-knot nematode Meloidogyne incognita infestation and the growth of tomato plants in the greenhouse and nursery. Journal of Invertebrate Pathology 100: 94-99.

[30] El-Hadad, M. E., Mustafa, M. I., Selim, S. M., ElTayeb, T. S., Mahgoob, A. E. A. and Abdel Aziz, N. H., 2011. The nematicidal effect of some bacterial biofertilizers on Meloidogyne incognita in sandy soil. Brazilian Journal of Microbiology 42: 105-113.

[31] Xia, Y.F., Xie, S.S., Ma, X., Wu, H.J., Wang, X. 2011. The purL gene of Bacillus subtilis is associated with nematicidal activity. FEMS Microbiology Letters 322: 99-107.

[32] Nagesh, M.; Asokan, R. and Mohan, K. S.2005.Partial characterization of novel nematicidal toxins from Bacillus cereus Frankland 1887 and their effect on root-knot nematode, Meloidogyne incognita ( Kofoid \& White) Chitwood. Journal of Biological Control 19 (1): 65-69.

[33] Bin, L., Guan-li,X., Soad,A. and Coosemans, J.2005. Suppression of Meloidogyne javanica by antagonistic and plant growth-promoting rhizobacteria. Journal Zhejiang University Science 6B(6): 496-501.

[34] Khan Z, Kim,S.G.,Jeon,Y.H., Khan,H.U.Son,S.H. and Kim ,Y.H.2008. A plant growth promoting rhizobacteriu m, Paenibacillus polymyxa strain GBR-1, suppresses root-knot nematode. Bioresource Technology 99: 3016-3023.

[35] Ying, H., Chuankun, X., Li, M., Keqin, Z., Chang, Q. D. and Ming, M. 2010. Characterisation of volatiles produced from Bacillus megaterium YFM325and their nematicidal activity against Meloidogyne incognita. European Journal of Plant Pathology 126:417-422

[36] Sankari Meena, K., Ramyabharathi, S. A. and Raguchander, T. 2014. Antimicrobial activity of Pseudomonas fluorescens against root knot nematode, Meloidogyne incognita in tomato, Lycopersicon esculentum Mill. 3rd International Conference on Agriculture \& Horticulture October 27-29, 2014 Hyderabad International Convention Centre, India. Agrotechnology 2014, 2:4

[37] Khan, Z., Park, S.D., Sh in, S.Y., Bae, S.G., Yeon, I.K. and Seo, Y.J. 2005.Management of Meloidogyne incognita on tomato by root-dip treatment inculture filtrate of the blue-green algae, Microcoleus vaginatus. Bioresource Technology 96: 1338-1341.

[38] Kiewnick, S. and Sikora, R.A. 2006. Biological control of the root-knot nematode Meloidogyne incognita by Paecilomyces lilacinus strain 251. Biological Control 38: 179-187. 
Table.1: Effect of culture filtrate of some bacterial bioagent on juvenile mortality of Meloidogyne incognita race 2.

\begin{tabular}{|c|c|c|c|c|c|c|}
\hline \multirow[t]{2}{*}{ Treatment } & \multirow{2}{*}{$\begin{array}{l}\text { Culture } \\
\text { filtrate } \\
\text { concentration }\end{array}$} & \multicolumn{3}{|c|}{ Period of exposure(h) } & \multirow{2}{*}{$\begin{array}{l}\text { Treatment } \\
\text { (T)Mean }\end{array}$} & \multirow{2}{*}{$\begin{array}{l}\text { Culture filtrate } \\
\text { concentration } \\
\text { (C)Mean }\end{array}$} \\
\hline & & 24 & 48 & 72 & & \\
\hline \multirow[t]{3}{*}{ Bacillus sp. } & $\mathrm{S} / 64$ & $36(36.85)$ & $55(47.87)$ & $85(67.21)$ & \multirow[t]{3}{*}{$62.00(52.79)$} & $43.62(39.61)$ \\
\hline & $\mathrm{S} / 16$ & $40(39.20)$ & $58(49.62)$ & $86(68.08)$ & & $48.85(44.26)$ \\
\hline & $\mathrm{S} / 4$ & $48(43.85)$ & $60(50.79)$ & $90(71.62)$ & & $51.66(46.20)$ \\
\hline \multirow[t]{3}{*}{ B.brevis } & $\mathrm{S} / 64$ & $38(38.04)$ & $60(50.79)$ & $70(56.79)$ & \multirow[t]{3}{*}{$63.44(53.81)$} & \\
\hline & $\mathrm{S} / 16$ & $42(40.38)$ & $62(51.94)$ & $90(71.94)$ & & \\
\hline & $\mathrm{S} / 4$ & $50(44.99)$ & $66(54.33)$ & $93(75.05)$ & & \\
\hline \multirow{3}{*}{ B.thuringiensis } & $\mathrm{S} / 64$ & $55(47.86)$ & $74(59.35)$ & $75(60.00)$ & \multirow[t]{3}{*}{$75.77(63.74)$} & \\
\hline & $\mathrm{S} / 16$ & $60(50.76)$ & $77(61.38)$ & $100(90.00)$ & & \\
\hline & $\mathrm{S} / 4$ & $62(51.94)$ & $79(62.74)$ & $100(90.00)$ & & \\
\hline \multirow[t]{3}{*}{ Pseudomonas sp. } & S/64 & $46(42.70)$ & $60(50.76)$ & $72(58.11)$ & \multirow[t]{3}{*}{$66.44(55.87)$} & \\
\hline & $\mathrm{S} / 16$ & $50(44.99)$ & $62(51.94)$ & $93(74.34)$ & & \\
\hline & $\mathrm{S} / 4$ & $52(46.14)$ & $68(55.64)$ & $95(75.07)$ & & \\
\hline \multirow[t]{3}{*}{ P.florescence } & $\mathrm{S} / 64$ & $58(49.60)$ & $74(59.35)$ & $76(60.67)$ & \multirow[t]{3}{*}{$75.44(63.52)$} & \\
\hline & $\mathrm{S} / 16$ & $58(49.60)$ & $75(60.00)$ & $100(90.00)$ & & \\
\hline & $\mathrm{S} / 4$ & $60(50.76)$ & $78(62.08)$ & $100(90.00)$ & & \\
\hline \multirow[t]{3}{*}{ P.aeruginosa } & S/64 & $38(38.04)$ & $48(43.85)$ & $82(64.91)$ & \multirow[t]{3}{*}{$59.55(51.13)$} & \\
\hline & $\mathrm{S} / 16$ & 42(40.39) & $52(46.14)$ & $84(66.44)$ & & \\
\hline & $\mathrm{S} / 4$ & $48(43.85)$ & $56(49.02)$ & $86(68.05)$ & & \\
\hline \multirow{3}{*}{$\begin{array}{l}\text { Culture } \\
\text { media(NA) }\end{array}$} & $\mathrm{S} / 64$ & $6(14.04)$ & $10(18.37)$ & $20(26.54)$ & \multirow[t]{3}{*}{$14.00(21.49)$} & \\
\hline & $\mathrm{S} / 16$ & $8(16.34)$ & $12(20.7)$ & $20(16.50)$ & & \\
\hline & $\mathrm{S} / 4$ & $10(18.37)$ & $18(25.07)$ & $22(27.94)$ & & \\
\hline \multirow{3}{*}{$\begin{array}{l}\text { Culture } \\
\text { media(KB) }\end{array}$} & $\mathrm{S} / 64$ & $8(16.34)$ & $10(18.37)$ & $16(23.54)$ & \multirow[t]{3}{*}{$14.00(21.75)$} & \\
\hline & $\mathrm{S} / 16$ & $12(20.22)$ & $12(20.22)$ & $18(25.07)$ & & \\
\hline & $\mathrm{S} / 4$ & $14(21.93)$ & $16(23.46)$ & $20(26.54)$ & & \\
\hline \multirow[t]{3}{*}{ Distilled water } & $S$ & $0(0.00)$ & $2(8.13)$ & $4(11.27)$ & \multirow[t]{3}{*}{$1.77(6.12)$} & \\
\hline & $\mathrm{S}$ & $0(0.00)$ & $2(8.13)$ & $4(11.27)$ & & \\
\hline & $\bar{S}$ & $0(0.00)$ & $2(8.13)$ & $2(8.13)$ & & \\
\hline $\begin{array}{l}\text { Period of } \\
\text { Exposure (t)Mean }\end{array}$ & & $\begin{array}{l}34.85 \\
(33.60)\end{array}$ & $\begin{array}{c}46.22 \\
(41.38)\end{array}$ & $\begin{array}{c}63.07 \\
(55.09)\end{array}$ & & \\
\hline \multicolumn{7}{|c|}{$\begin{array}{l}\mathrm{CV}=4.47, \mathrm{CD}(\mathrm{P}=0.05): \text { Treatment(T):1.03; Concentration }(\mathrm{C}): 0.59 ; \text { Period of exposure }(\mathrm{t}): 0.59 ; \mathrm{T} \times \mathrm{C}: 1.79 ; \mathrm{T} \times \mathrm{t}: 1.79 ; \\
\mathrm{C} \times \mathrm{t}: 1.50 ; \mathrm{T} \times \mathrm{C} \times \mathrm{t}: 3.10\end{array}$} \\
\hline
\end{tabular}

Figures in the parentheses are Arc-Sine transformed values

Table.2: Effect of culture filtrate of some bacterial bioagent on hatching of Meloidogyne incognita race 2.

\begin{tabular}{|c|c|c|c|c|c|c|}
\hline \multirow[t]{2}{*}{ Treatment } & \multirow{2}{*}{$\begin{array}{l}\text { Culture } \\
\text { filtrate } \\
\text { concentration } \\
(\%)\end{array}$} & \multicolumn{3}{|c|}{ Period of exposure(days) } & \multirow{2}{*}{$\begin{array}{c}\text { Treatment } \\
\text { Mean }\end{array}$} & \multirow{2}{*}{$\begin{array}{c}\text { Culture filtrate } \\
\text { concentration } \\
\text { Mean }\end{array}$} \\
\hline & & 5 & 10 & 15 & & \\
\hline \multirow[t]{3}{*}{ Bacillus sp. } & $\mathrm{S} / 64$ & $32(34.43)$ & $38(38.04)$ & $52(46.14)$ & \multirow{3}{*}{$\begin{array}{c}35.33 \\
(36.32)\end{array}$} & $52.25(46.61)$ \\
\hline & $\mathrm{S} / 16$ & $26(30.65)$ & $34(35.66)$ & $44(41.54)$ & & $48.70(44.35)$ \\
\hline & $\mathrm{S} / 4$ & $22(27.94)$ & $32(34.43)$ & $38(38.04)$ & & $45.74(42.47)$ \\
\hline \multirow[t]{2}{*}{ B.brevis } & S/64 & $39(38.63)$ & $48(43.85)$ & $56(48.44)$ & \multirow{2}{*}{$\begin{array}{c}43.11 \\
(41.01)\end{array}$} & \\
\hline & $\mathrm{S} / 16$ & $30(33.19)$ & $45(42.70)$ & $52(46.14)$ & & \\
\hline
\end{tabular}




\begin{tabular}{|c|c|c|c|c|c|c|}
\hline & $\mathrm{S} / 4$ & $28(31.93)$ & $40(39.22)$ & $50(44.99)$ & & \\
\hline \multirow[t]{3}{*}{ B.thuringiensis } & S/64 & $22(27.95)$ & $30(33.19)$ & $38(38.04)$ & \multirow{3}{*}{$\begin{array}{c}26.55 \\
(30.77)\end{array}$} & \\
\hline & $\mathrm{S} / 16$ & $18(25.07)$ & $26(30.64)$ & $36(36.86)$ & & \\
\hline & $\mathrm{S} / 4$ & $15(22.71)$ & $22(27.95)$ & $32(34.43)$ & & \\
\hline \multirow[t]{3}{*}{ Pseudomonas sp. } & S/64 & $30(33.19)$ & $40(39.22)$ & $48(43.85)$ & \multirow{3}{*}{$\begin{array}{c}37.77 \\
(37.87)\end{array}$} & \\
\hline & $\mathrm{S} / 16$ & $36(36.86)$ & $38(38.04)$ & $44(41.55)$ & & \\
\hline & $\mathrm{S} / 4$ & $32(34.43)$ & $32(34.43)$ & $40(39.22)$ & & \\
\hline \multirow[t]{3}{*}{ P.florescence } & $\mathrm{S} / 64$ & $34(35.66)$ & $42(40.39)$ & $50(44.99)$ & \multirow{3}{*}{$\begin{array}{c}36.66 \\
(37.09)\end{array}$} & \\
\hline & $\mathrm{S} / 16$ & $24(29.32)$ & $38(38.04)$ & $46(42.70)$ & & \\
\hline & $\mathrm{S} / 4$ & $22(27.95)$ & $30(33.19)$ & $44(41.55)$ & & \\
\hline \multirow[t]{3}{*}{ P.aeruginosa } & S/64 & $34(35.66)$ & $44(41.54)$ & $50(44.99)$ & \multirow{3}{*}{$\begin{array}{c}38.66 \\
(38.32)\end{array}$} & \\
\hline & $\mathrm{S} / 16$ & $28(31.93)$ & $38(38.03)$ & $48(43.85)$ & & \\
\hline & $\mathrm{S} / 4$ & $24(29.31)$ & $36(36.85)$ & $46(42.70)$ & & \\
\hline \multirow{3}{*}{$\begin{array}{l}\text { Culture } \\
\text { media(NA) }\end{array}$} & $\mathrm{S} / 64$ & $64(53.12)$ & $78(62.03)$ & $82(64.91)$ & \multirow{3}{*}{$\begin{array}{c}72.33 \\
(58.47)\end{array}$} & \\
\hline & $\mathrm{S} / 16$ & $63(52.53)$ & $74(59.35)$ & $80(63.44)$ & & \\
\hline & $\mathrm{S} / 4$ & $60(50.76)$ & $72(58.05)$ & $78(62.03)$ & & \\
\hline \multirow{3}{*}{$\begin{array}{l}\text { Culture } \\
\text { media }(\mathrm{KB})\end{array}$} & S/64 & $67(54.93)$ & $78(62.03)$ & $82(64.93)$ & \multirow{3}{*}{$\begin{array}{c}73.55 \\
(59.24)\end{array}$} & \\
\hline & $\mathrm{S} / 16$ & $64(53.12)$ & $76(60.66)$ & $80(63.44)$ & & \\
\hline & $\mathrm{S} / 4$ & $62(51.94)$ & $75(60.00)$ & $78(62.03)$ & & \\
\hline \multirow[t]{3}{*}{ Distilled water } & $\mathrm{S}$ & $70(59.02)$ & $79(62.72)$ & $84(66.49)$ & \multirow{3}{*}{$\begin{array}{c}76.11 \\
(61.19)\end{array}$} & \\
\hline & $\mathrm{S}$ & $67(54.93)$ & $78(62.16)$ & $82(64.91)$ & & \\
\hline & $\mathrm{S}$ & $67(54.95)$ & $78(62.03)$ & $80(63.44)$ & & \\
\hline $\begin{array}{l}\text { Period of } \\
\text { Exposure } \\
\text { (t)Mean }\end{array}$ & & $\begin{array}{l}40.00 \\
(38.97)\end{array}$ & $\begin{array}{c}49.66 \\
(44.98)\end{array}$ & $\begin{array}{c}57.03 \\
(49.47)\end{array}$ & & \\
\hline \multicolumn{7}{|c|}{$\begin{array}{l}\mathrm{CV}=3.33, \mathrm{CD}(\mathrm{P}=0.05): \text { Treatment }(\mathrm{T}): 0.78 ; \text { Concentration }(\mathrm{C}): 0.45 ; \text { Period of exposure }(\mathrm{t}): 0.45 ; \mathrm{T} \times \mathrm{C}: 1.35 ; \mathrm{T} \times \mathrm{t}: 1.35 ; \\
\mathrm{C} \times \mathrm{t}: 0.78 ; \mathrm{T} \times \mathrm{C} \times \mathrm{t}: 2.34\end{array}$} \\
\hline
\end{tabular}

Figures in the parentheses are Arc-Sine transformed values 